\title{
The Ly49 gene family. A brief guide to the nomenclature, genetics, and role in intracellular infection
}

\author{
Alan Rowe Schenkel ${ }^{1}{ }^{*}$, Luke C. Kingry ${ }^{1,2}$ and Richard A. Slayden ${ }^{1}$ \\ 1 Department of Microbiology, Immunology and Pathology, Colorado State University, Fort Collins, CO, USA \\ ${ }^{2}$ Division of Vector Borne Diseases, Centers for Disease Control and Prevention, Fort Collins, CO, USA
}

\section{Edited by:}

Claudia Monaco, Catholic University

Rome and Imperial College, UK

Reviewed by:

Stephen K. Anderson, National

Cancer Institute, USA

Daisuke Kamimura, Osaka University

Japan

*Correspondence:

Alan Rowe Schenkel, Department of

Microbiology, Immunology and

Pathology, Colorado State University,

1682 Campus Delivery, Fort Collins,

CO 820526, USA.

e-mail: alan.schenkel@colostate.edu
Understanding the Ly49 gene family can be challenging in terms of nomenclature and genetic organization. The Ly49 gene family has two major gene nomenclature systems, Ly49 and Killer Cell Lectin-like Receptor subfamily A (klra). Mice from different strains have varying numbers of these genes with strain specific allelic variants, duplications, deletions, and pseudogene sequences. Some members activate NK lymphocytes, invariant NKT (iNKT) lymphocytes and $\gamma \delta T$ lymphocytes while others inhibit killing activity. One family member, Ly49Q, is expressed only on myeloid cells and is not found on NK, iNKT, or $\gamma \delta$ $\mathrm{T}$ cells. There is growing evidence that these receptors may regulate not just the immune response to viruses, but other intracellular pathogens as well. Thus, this review's primary goal is to provide a guide for researchers first encountering the Ly 49 gene family and a foundation for future studies on the role that these gene products play in the immune response, particularly the response to intracellular viral and bacterial pathogens.

Keywords: Ly49, kIra, natural killer lymphocytes, myeloid cells

\section{INTRODUCTION}

The highly polymorphic Ly49 genes serve as a reminder that nature and evolution occasionally conspire to resist systematic classification schemes. The first gene in this family was identified as a "T lymphocyte activation marker" and became Ly49A (Chan and Takei, 1989; Yokoyama et al., 1989). However, expression of Ly49A is found primarily on Natural Killer (NK), invariant NK T (To et al., 2009), and NK1.1+ $\gamma \delta \mathrm{T}$ lymphocytes (Hara et al., 2001). On T lymphocytes, it is found only on a subset of CD3+ T cells which were also NK1.1 - and/or DX5 - (Ortaldo et al., 1998) and a subset of CD8+ Tregs (Kim et al., 2011). The first identified function of the Ly49 genes was as an inhibitor of NK lymphocyte killing of tumor cell lines that express MHC Class I. NK killing was inhibited by Ly49A recognition of $\mathrm{H} 2-\mathrm{D}^{\mathrm{d}}$ on the tumor cells (Yokoyama and Seaman, 1993). It was subsequently found that some Ly49 genes inhibited killing but others activated killing, both via interactions with MHC Class I molecules and other molecules like murine cytomegalovirus $\mathrm{m} 157$ on the surface of target cells (Makrigiannis and Anderson, 2000). Discoveries of more genes in the family quickly revealed that there was significant genomic complexity in the gene family, with different strains of mice having varying numbers of gene segments, arising in part from duplication events. Several Ly49 genomic sequences are non-functional pseudogenes (Yokoyama and Seaman, 1993; Smith et al., 1994).

Both inhibitory and activating Ly49 have the same basic structure, with a stalk and a natural killer receptor domain (NKD). They exist as homodimers on the surface of the cell, and interact with ligands via the NKD structures. However, inhibitory and activating Ly49 signal differently to the cell upon recognition of their ligands. The inhibitory Ly 49 genes have a conserved Immunoreceptor Tyrosine-based Inhibitory motif (ITIM) domain on their cytoplasmic tails (Belanger et al., 2008). Activating Ly49 genes have a transmembrane arginine residue and associate with the signal adapter proteins DAP10 and DAP12. DAP12 is important for signaling but the requirement of DAP 10 for signaling is potentially minimal (Tassi et al., 2009).

Perhaps unsurprisingly, this gene family also highlights the differences and similarities between mice and humans. Unlike other mammals such as rodents and cattle, the human genome does not encode Ly49 genes (Dissen et al., 2008). Instead, humans have the Killer Immunoglobulin-like Receptors (KIR) fulfilling the same role, and, like the Ly49 genes, KIR are highly polymorphic with both activating and inhibitory receptors. The genes are not genetically homologous to the Ly49 genes, but rather have a parallel function (Middleton and Gonzelez, 2010), and do appear to have evolved from similar duplication events as those seen in the Ly49 genes (Martin et al., 2000). Accordingly, the functional role the Ly49 genes may serve as a model to understand how KIR participate in the immune responses of human NK cells.

\section{GENOMICS OF THE Ly49 GENES}

Soon after cloning Ly49A, southern blots and analysis of mRNA transcripts revealed that there were several members of the Ly49 family (Yokoyama and Seaman, 1993; Smith et al., 1994), which has subsequently expanded to include approximately 20-30 members, including many pseudogenes (Table 1) (Makrigiannis and Anderson, 2000; Makrigiannis et al., 2001; Lavender and Kane, 2006; Kielczewska et al., 2007; Scarpellino et al., 2007; Belanger et al., 2008; Jonsson et al., 2010). This cluster was mapped to chromosome 6 (Yokoyama et al., 1990), mostly in tandem as shown in Figure 1, with the exception of Ly49B. Ly49B is also located on Chromosome 6 but not within the Ly49 cluster. Many gene segments, either fully functional genes or pseudogenes, are indicated by the nomenclature Ly49A-Ly49X and with the strain in 
Table 1 | Combined nomenclature and ligands of the Ly49 genes.

\begin{tabular}{|c|c|c|c|c|c|}
\hline $\begin{array}{l}\text { Ly49 } \\
\text { GenBank }\end{array}$ & Ly49 NOD & Klra number & Role, strain, other notes & $\begin{array}{l}\text { Other aliases, } \\
\text { previous names } \\
\text { or homologs }\end{array}$ & Ligands \\
\hline Ly49A & Ly49a & Klra1 & $\begin{array}{l}\text { Inhibitory. C57/BL/6 (B6), } \\
\text { NODShiLtJ (NOD), } 129 \text { and Balb/c }\end{array}$ & $\begin{array}{l}\text { A1, Klra22, Ly49o'129 } \\
\text { (Ly49V) }\end{array}$ & $\begin{array}{l}\text { H2-Dd, H2-D }{ }^{r}, H 2-D^{k}, H 2-D^{p} \\
\text { (Makrigiannis and Anderson, 2000; } \\
\text { Scarpellino et al., 2007; Jonsson } \\
\text { et al., 2010). B6 strain: H2-L }{ }^{d}, H 2-D^{d} \\
\text { H2-Kb H2-D (Johansson et al., 2009) }\end{array}$ \\
\hline Ly49B & & Klra2 & $\begin{array}{l}\text { Inhibitory B6, 129, Balb/c. Two } \\
\text { isoforms (splice variants). Unique } \\
\text { locus } 5 \text { ' from all other Ly } 49 \text { genes }\end{array}$ & Klra30 & Unknown \\
\hline Ly49D & Ly49d & Klra4 & $\begin{array}{l}\text { Activator. B6 (2 isoforms) and NOD } \\
\text { only }\end{array}$ & $\begin{array}{l}\text { Chok, Klra32, } \\
\text { Ly49r }{ }^{129}\end{array}$ & $\begin{array}{l}\mathrm{H}_{2}-\mathrm{D}^{\mathrm{d}}, \mathrm{H} 2-\mathrm{D}^{\mathrm{r}}, \mathrm{H} 2-\mathrm{D}^{\mathrm{sp} 2} \text { (Makrigiannis } \\
\text { and Anderson, 2000) }\end{array}$ \\
\hline Ly49E & Ly49e & Klra5 & $\begin{array}{l}\text { Inhibitory Balb/c, NOD, B6, and } \\
129 \text { (Aust et al., 2011) }\end{array}$ & & $\begin{array}{l}\text { Urokinase plasminogen activator (Van } \\
\text { Den Broeck et al., 2008) }\end{array}$ \\
\hline Ly49e/c & & Klra26, Klra27 & $\begin{array}{l}\text { Pseudogene } 129 \text { has Ly49ec1 }{ }^{129} \\
{\text { Ly } 49 e c 2^{129}}^{12} \text { (Belanger et al., 2008) }\end{array}$ & & N/A \\
\hline Ly49H & Ly49h & Klra8 & Activator. B6 and NOD only & Cmv1, Ly49u'129 & $\begin{array}{l}\text { CMV m157 (Arase et al., 2002; } \\
\text { Kielczewska et al., 2007), } \\
\text { H2-Db (Dimasi and Biassoni, 2005) }\end{array}$ \\
\hline Ly491 & $\begin{array}{l}\text { Ly49i1 }=I T I M \\
\text { Ly49i2 }=\psi \\
\text { Ly49i3 }=\psi\end{array}$ & Klra9 & $\begin{array}{l}\text { Inhibitor }+\mathbf{2} \text { pseudogenes in } \\
\text { NOD; i1 and i2 } \psi \text { in } 129 \text { mice, one i } \\
\text { in B6 and Balb/c }\end{array}$ & & 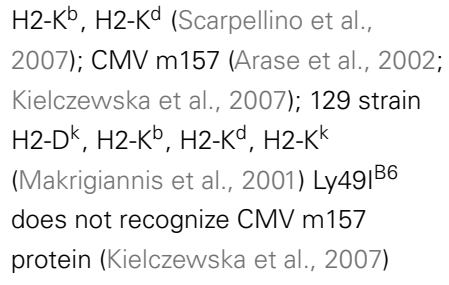 \\
\hline Ly49J & & Klra10 & Pseudogene in $B 6$ & Ly49i2 & N/A \\
\hline Ly49K & & Klra11 & Pseudogene B6 only & & Unknown \\
\hline
\end{tabular}


Table 1 | Continued

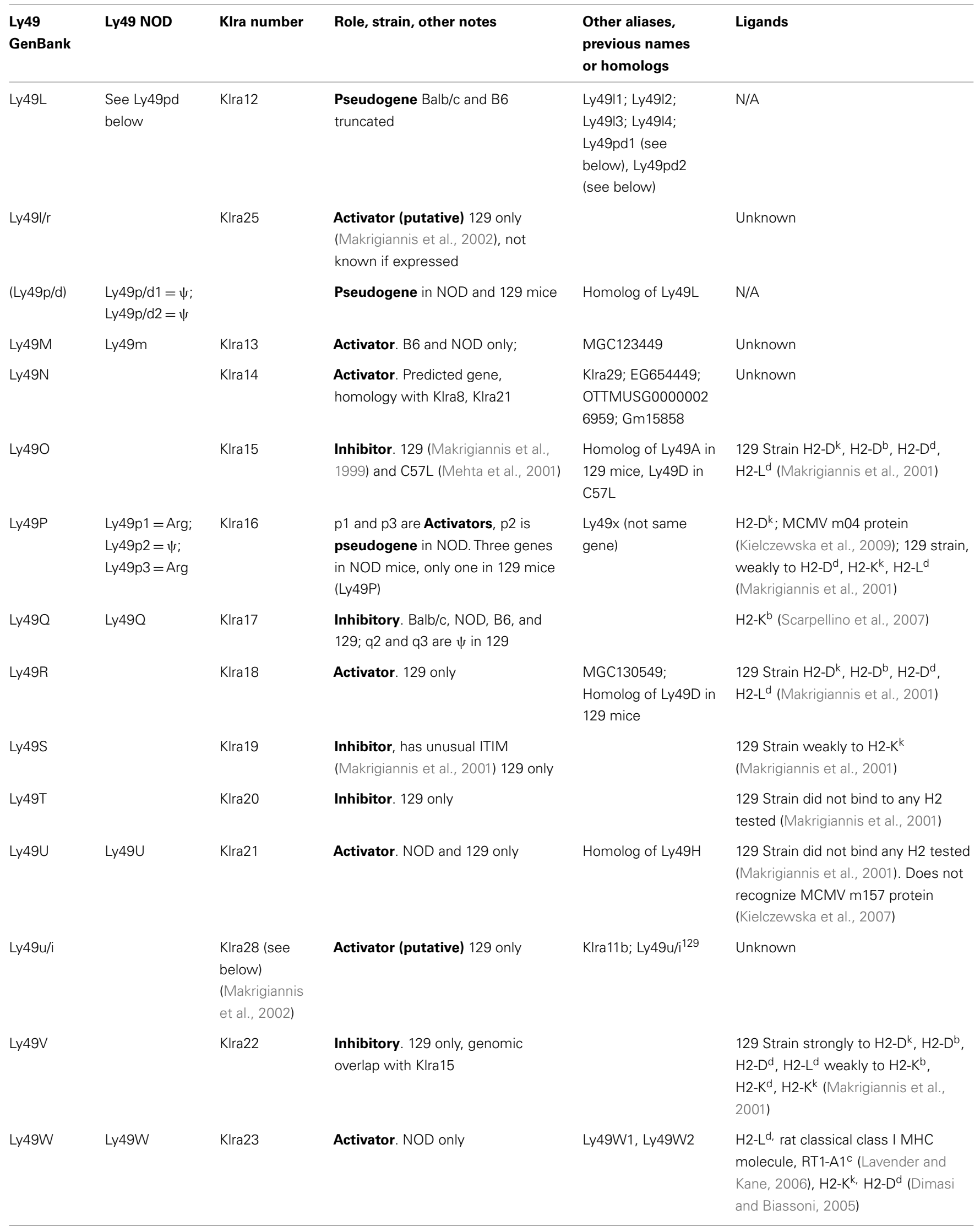


Table 1 | Continued

\begin{tabular}{|c|c|c|c|c|c|}
\hline $\begin{array}{l}\text { Ly49 } \\
\text { GenBank }\end{array}$ & Ly49 NOD & KIra number & Role, strain, other notes & $\begin{array}{l}\text { Other aliases, } \\
\text { previous names } \\
\text { or homologs }\end{array}$ & Ligands \\
\hline Ly49X & & KIra24 & Pseudogene in NOD, and B6 mice & & N/A \\
\hline Ly49l/r & Ly49I/r & KIra25 & $\begin{array}{l}\text { Activator (putative) } 129 \text { only } \\
\text { (Makrigiannis et al., 2002), not } \\
\text { known if expressed }\end{array}$ & & Unknown \\
\hline \multirow[t]{5}{*}{ Ly49Y } & & & $\begin{array}{l}\text { Pseudogene Balb/c only (Orr and } \\
\text { Lanier, 2011) }\end{array}$ & & $\mathrm{N} / \mathrm{A}$ \\
\hline & & KIra26 & Pseudogene 129 only & Ly49e/c1 & Unknown \\
\hline & & KIra27 & Pseudogene 129 only & Ly49e/c2 & Unknown \\
\hline & & $\begin{array}{l}\text { Klra28 } \\
\text { (Makrigiannis } \\
\text { et al., 2002) }\end{array}$ & Activator (putative) 129 only & KIra11b; Ly49u/i129 & Unknown \\
\hline & & KIra14 (KIra29) & $\begin{array}{l}\text { Activator. Predicted gene, } \\
\text { homology with Klra8, Klra21 }\end{array}$ & $\begin{array}{l}\text { EG654449; } \\
\text { OTTMUSG00000026959; } \\
\text { Gm15858 }\end{array}$ & Unknown \\
\hline \multirow[t]{3}{*}{ Ly49B } & & Klra30 & $\begin{array}{l}\text { Activator. B6, 129, Balb/c. Two } \\
\text { isoforms (splice variants) }\end{array}$ & Ly49b, KIra2 & See Ly49B above \\
\hline & & Klra31 & & & Unknown \\
\hline & & KIra32 & & Homolog of Ly49D? & Unknown \\
\hline
\end{tabular}

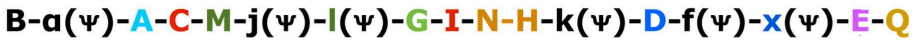

Balb/c

$$
\text { B-a( } \Psi)-A-C-I(\Psi)-G-I-y(\Psi)-E-Q
$$

FIGURE 1 | Genomic Organization in the four known mouse strains. Color coded to match Table $\mathbf{3}$ and Belanger et al. (2008).

Uppercase gene is known to be expressed. Pseudogenes indicated with a psi symbol. Underlined sections indicate regions common in 129 and NOD mice that have also undergone duplication in NOD mice (Belanger et al., 2008). superscript indicating the strain allelic variants, e.g., Ly49A $\mathrm{A}^{\mathrm{Balb} / \mathrm{c}}$, Ly49A ${ }^{\text {C57BL/6 }}$, or Ly49C $\mathrm{C}^{\mathrm{C} 5 \mathrm{BL} / 6}$. The first published usage of Killer Cell Lectin-like Receptor subfamily A (Klra) introduced a different systematic nomenclature system (Lee et al., 2001), which has been adopted by GenBank. GenBank also uses the Ly49 nomenclature and this can be confusing to researchers when they first encounter these two nomenclature systems. In our opinion, the use of the Ly49 with superscript strain nomenclature is the clearest and will be the system used by this review. In Figure 1 and Table 2, we will also use the shortened name, Ly49A $\mathrm{A}^{\mathrm{C} 57 \mathrm{BL} / 6}$ as $\mathrm{A}^{\mathrm{B} 6}$ for example. Similarly, we believe it would be useful to instead modify the klra nomenclature to klra1 ${ }^{\mathrm{C} 57 \mathrm{BL} / 6}$.

There are two other aspects of Ly49 genes that add substantial complexity to their classification. Most surprisingly, different mouse strains have different numbers of the Ly49 genes encoded in the genome. The Makrigiannis lab has provided the best analyses of the genomics of the Ly49 genes so far and they found that some mouse strains, like Balb/c, have relatively few Ly49 genes with just nine, while the Non-obese Diabetic Mouse (NOD/ShiLtJ or NOD) strain has the most known to date with 22 Ly49 gene segments, nine of which are pseudogenes (Belanger et al., 2008). Additionally, the same genes vary in homology from strain to strain (Table 2; Figure 1). For example, Ly49E $\mathrm{E}^{\mathrm{Balb} / \mathrm{c}}$ is homologous but not identical to Ly49E $\mathrm{E}^{\mathrm{NOD}}$. This diversity of the $\mathrm{Ly} 49^{\mathrm{NOD}}$ genes is very complex, due in part to duplications and pseudogenes (Figure 1). This is shown as a separate column in Table 1 and grouped into families in Table 2. Some of the genes have partial homology to two or more different 
genes and did not fit into the original nomenclature, for example, Ly $49 \mathrm{p} / \mathrm{d}^{\mathrm{NOD}}$ in Table 1, which shares partial homology with Ly49P at exon 3 and Ly49D at exon 4. The cloning process resulted in a few of these gene designations and were kept after complete sequencing to avoid further confusion, even if other exons showed homology to other Ly49 genes (Makrigiannis, personal communication).

Table 2 groups the genes into related families and updates data from a dendrogram in the NOD mouse study (Belanger et al., 2008). We've expanded it to include Ly49B and two members not included in that study, Ly49S ${ }^{129}$ and Ly49O ${ }^{129}$. Furthermore, there have long been close relationships in homology and antigenicity within the families, establishing groups shown in the same color on Table 2 based on the branches of the dendrogram by Belanger et al. (2008). A prime example of a closely related family is Ly49C,

\section{Table 2 | Ly49 gene groups.}

\begin{tabular}{|c|c|}
\hline A group (inhibitory) & $a^{\mathrm{B} 6,} \mathrm{a}^{\mathrm{NOD}}, \mathrm{a}^{\mathrm{Balb}}, \mathrm{o}^{129 *}$ \\
\hline G group (inhibitory) & $t^{129}, g_{1-2}{ }^{N O D}, g^{B 6}, g^{129}, g^{\text {Balb }}$ \\
\hline D group (activating) & $\begin{array}{l}d^{B 6}, d^{N O D}, p_{1-3}{ }^{N O D}, p^{129}, p d^{129}, p d_{1-2}{ }^{N O D}, x^{B 6}, \\
x^{N O D}, r^{129}\end{array}$ \\
\hline L group (activating) & $1^{B a l b}, w^{N O D}, m^{B 6}, m^{N O D}$ \\
\hline C group (inhibitory) & $\mathrm{i}_{1-2} \mathrm{NOD}, \mathrm{i}_{1} 129, i^{\mathrm{B} 6}, i^{\mathrm{Balb}}, \mathrm{c}^{\mathrm{NOD}}, c^{\mathrm{Balb} / \mathrm{c}}, c^{\mathrm{B} 6}$ \\
\hline E group (inhibitory) & $e^{N O D}, e^{B 6}, e^{129}, e^{B a l b}, f^{N O D}, f^{B 6}, s^{129 * *}$ \\
\hline $\mathrm{H}$ group (activating) & $n^{B 6}, k^{B 6}, h^{B 6}, h^{N O D}, u^{N O D}, u^{129}$ \\
\hline Q group (inhibitory) & $\mathrm{q}_{1}{ }^{129}, \mathrm{q}^{\mathrm{NOD}}, \mathrm{q}^{\mathrm{B} 6}, \mathrm{q}^{\mathrm{Balb} / \mathrm{c}}$ \\
\hline B group (inhibitory) & $b^{129}, b^{B 6}, b^{\text {Ballb/c }}$ \\
\hline
\end{tabular}

Based on homology, genomic organization, and function (Belanger et al., 2008), groups of Ly49 genes can be clustered as above.
Ly49F, Ly49I, and Ly49H, which are recognized by some of the same monoclonal antibodies like SW5E6 and 14B11 (Table 3). It is important to note that the monoclonal antibody made in one strain won't recognize the alleles from that same strain. For example, SW5E6 was made in 129 and won't recognize Ly49I ${ }^{129}$ (Makrigiannis, personal communication).

There are 26 known rat Ly 49 genes as well. The Ly 49 genes in rat appear to be fairly distant from the mouse homologs, with Ly49i8 showing homology to mouse Ly49B, and mouse Ly49Q somewhat similar to a small cluster of 7 rat Ly 49 genes from 26 functional genes. The rat gene cluster also has numerous pseudogenes (Nylenna et al., 2005).

\section{LIGANDS}

Many Ly49 genes recognize "self" ligands like the MHC Class I molecules H2-D, H2-L, and H2-K (Table 1) (Makrigiannis and Anderson, 2000; Makrigiannis et al., 2001; Dimasi and Biassoni, 2005; Lavender and Kane, 2006; Kielczewska et al., 2007; Scarpellino et al., 2007; Belanger et al., 2008; Jonsson et al., 2010). The inhibitory Ly49 receptors, like Ly49A, prevent killing upon recognition of their cognate ligand. This is not always strain specific recognition. For example, NK cells expressing Ly $49 \mathrm{~A}^{\mathrm{B} 6}$, which recognize $\mathrm{H} 2-\mathrm{D}^{\mathrm{b}}$ and $\mathrm{H} 2-\mathrm{K}^{\mathrm{b}}$ from $\mathrm{B} 6$ mice, can also recognize $\mathrm{H} 2-\mathrm{L}^{\mathrm{d}}$ and $\mathrm{H} 2-\mathrm{D}^{\mathrm{d}}$ which are expressed in other mouse strains (Johansson et al., 2009). The absence of these ligands or "missing self" on target cells combined with other activating signals to the NK lymphocyte triggers a cytolytic response by the NK cell against the target cells. The inhibitory Ly49 genes can recognize their ligands both in cis (on the same cell) and trans (on adjacent cells) (Back et al., 2009) which involves a molecular shift in the shapes of the molecules (Back et al., 2011). This has been modeled with Ly49A dimers interacting with pairs of H2-D molecules

Table 3 | Expression and binding antibody clones.

\begin{tabular}{|c|c|c|}
\hline Ly49 & Expression & Antibodies \\
\hline Ly49A & $\begin{array}{l}\text { NK, NKT (To et al., 2009), NK1.1+ } \gamma \delta \text { (Hara et al., 2001), subset NK1.1-/DX5-/CD3+ } \\
\text { T (Ortaldo et al., 1998); subset of CD8+ Tregs (Kim et al., 2011) }\end{array}$ & $\begin{array}{l}\text { 12A8, A1 (B6), JR9-318 (B6, Balb/c); YE1/32, YE1/48 } \\
\text { (Held et al., 1995) }\end{array}$ \\
\hline Ly49B & $\begin{array}{l}\text { CD11b+/F4/80+/Gr1+ myeloid cells, activated NK, iNKT cell line, granulocytes } \\
\text { (neutrophils, eosinophils, mast cells) macrophages, independent of Ly490 (Held } \\
\text { et al., 1995; Gays et al., 2006) }\end{array}$ & 1A1 (Gays et al., 2006) \\
\hline Ly49C & $\begin{array}{l}\text { NK, NKT (To et al., 2009), NK1.1+ } \gamma \delta \text { (Hara et al., 2001), subset NK1.1-/DX5-/CD3+ } \\
\text { T (Ortaldo et al., 1998); subset of CD8+Tregs (Kim et al., 2011) }\end{array}$ & Ly49C/I SW5E6; Ly49C/F/I/HB6 14B11 \\
\hline Ly49D & NK only, not on DX5-T (Ortaldo et al., 1998) & 4E5; $12 \mathrm{~A} 1$ \\
\hline Ly49E & Fetal NK, thymic NKT (Aust et al., 2011), $\gamma \delta T$ Nan Beneden et al., 2001) & $\begin{array}{l}\text { Ly49E/C binds 4D12 Nan Beneden et al., 2002) CM4 } \\
\text { (Ly49E/F) (Aust et al., 2011) }\end{array}$ \\
\hline Ly49F & Expression unclear (Corral et al., 1999); CD8+ Tregs (Kim et al., 2011) & Ly49C/I/H $14 \mathrm{~B} 611$ \\
\hline Ly49G & $\begin{array}{l}\text { NK, NK T (To et al., 2009), NK1.1+ } \gamma \delta(\text { Hara et al., 2001), subset NK1.1-/DX5-/CD3+ } \\
\text { T (Ortaldo et al., 1998); subset of CD8+ Tregs (Kim et al., 2011) }\end{array}$ & 4D11; Ly49G2 ${ }^{\text {B6 }}$ Cwy-3; Ly49G ${ }^{129 / B a l b}$ AT8 \\
\hline Ly49H & NK, others unknown & 14B11 which recognizes Ly49C/F/I (Corral et al., 1999) \\
\hline Ly491 & NK, NKT (To et al., 2009), NK1.1+ $\gamma \delta($ Hara et al., 2001) & 3D10; Ly49C/I SW5E6; Ly49C/I/F/H'B6 14B11 \\
\hline Ly490 & $\begin{array}{l}\text { Myeloid cells CD11b+/B220+/CD4+, and/or CD8+ (Toyama-Sorimachi et al., 2004); } \\
\text { pDCs (Kamogawa-Schifter et al., 2005); and Osteoclasts (Hayashi et al., 2010) }\end{array}$ & \\
\hline Ly490 & NK, others unknown & YE1/32, YE1/48 (Held et al., 1995) \\
\hline Ly49V & NK & $4 E 5$ \\
\hline
\end{tabular}


in trans via an open conformation of the NKD interacting with $\beta 2$ microglobulin and the $\alpha 3$ domain of $\mathrm{H} 2-\mathrm{D}^{\mathrm{d}}$ on adjacent cells. This sends inhibitory signals to the NK cell. In cis conformations, the NKD dimers of Ly49C can interact with one $\mathrm{H} 2-\mathrm{K}^{\mathrm{b}}$ in a closed conformation and, by inhibiting this inhibitory molecule, decreasing the activation threshold of the NK cell (Dam et al., 2003; Held and Mariuzza, 2008; Back et al., 2009, 2011).

Many activating Ly49 receptors also bind to MHC Class I molecules (Dimasi and Biassoni, 2005), but this is primarily recognition of different strain alleles or "non-self/altered-self" MHC molecules, and is defined using allogenic cytotoxic assays used to characterize the function of these receptors in vitro. In addition to recognition of mouse surface proteins, Ly $49 \mathrm{~W}^{\mathrm{NOD}}$ and $\mathrm{Ly} 49 \mathrm{G}^{\mathrm{Balb} / \mathrm{c}}$ can xenogenically recognize the rat class I MHC molecule, RT1-A1 ${ }^{\mathrm{c}}$ (Lavender and Kane, 2006). Ly49D ${ }^{\mathrm{B} 6}$ can be activated by Chinese hamster ovary $(\mathrm{CHO})$ cells by a molecule mapped to the chok locus. The closely related C57L strain of mice also seems to interact with $\mathrm{CHO}$ cells using $\mathrm{Ly} 49 \mathrm{O}^{\mathrm{C} 57 \mathrm{~L}}$ which is very homologous to $\mathrm{Ly} 49 \mathrm{D}^{\mathrm{B} 6}$ and reacts to the $4 \mathrm{E} 4$ antibody, yet is an inhibitory Ly49 (Mehta et al., 2001).

There is substantial evidence for tolerance and restriction by self MHC Class I molecules and regulating development ("licensing”) of NK cells via specific Ly49 genes (Lowin-Kropf et al., 2000; Kim et al., 2005). Studies using NK cells expressing single Ly49 molecules combined with transgenic expression of single MHC Class I ligands showed that Ly49 binding is not restricted as originally thought. Instead, many Ly 49 molecules can recognize several different MHC class I molecules (Brodin et al., 2012). Belanger et al. (2008) have also used transgenic mice in which the Ly49O gene was targeted. They discovered that disruption of Ly49O unintentionally lowered transcription of all Ly49 genes. NK cells from these Ly49-knockdown mice were tested for killing against cells expressing or lacking MHC Class I genes in vivo and in vitro. It was found that killing of cells lacking MHC Class I was impaired by NK cells from these mice and could be rescued by restoring Ly49I expression, which is a strong inhibitory receptor for both $\mathrm{H}-2 \mathrm{~K}^{\mathrm{b}}$ and $\mathrm{H}-2 \mathrm{D}^{\mathrm{b}}$, but not by restoring Ly49A or Ly49G (Cheng et al., 2008).

Many viruses, such as those in the herpes family, inhibit surface expression of MHC Class I molecules as a way of preventing recognition by conventional cytotoxic $\mathrm{CD} 8+, \alpha \beta \mathrm{T}$ cell receptor + T lymphocytes (Loch and Tampe, 2005). Although this allows the virus to hide in the cell from these classical T lymphocytes, infected cells are vulnerable to killing by NK cells. When activating Ly49 receptors recognize their viral ligands, such as the mouse herpes virus cytomegalovirus (MCMV) protein m157 by Ly $49 \mathrm{H}$, this triggers a cytolytic response in the NK cells against the infected cells (Dimasi and Biassoni, 2005). MCMV protein $\mathrm{m} 157$ is a ligand for $\mathrm{Ly} 49 \mathrm{H}^{\mathrm{B} 6}$, $\mathrm{Ly} 49 \mathrm{H}^{\mathrm{NOD} /}$, and $\mathrm{Ly} 49 \mathrm{I}^{129}$ (Arase et al., 2002). However, similar genes from different strains of mice, Ly49I ${ }^{\mathrm{B} 6}$ for example, do not recognize m157 (Tay et al., 1999; Kielczewska et al., 2007). Additionally, m157 variants can escape binding to $\mathrm{Ly} 49 \mathrm{H}^{\mathrm{B} 6}$. Ly49 $\mathrm{C}^{\mathrm{B} 6}$ and $\mathrm{Ly} 49 \mathrm{C}^{\mathrm{Balb}}$ also can bind to some m157 variants but these interactions do not appear to be critical for viral resistance (Corbett et al., 2011). Ly49H seems to be most critical for resistance to MCMV, but does not mediate resistance to herpes simplex virus 1 or ectromelia virus (Cheng et al., 2008). Another MCMV ligand for Ly49P is m04, which is a viral protein that may play a role in $\mathrm{H} 2-\mathrm{D}^{\mathrm{k}}$ stabilization (Kielczewska et al., 2009). The development of memory-like NK cells, which expand, contract, and persist like other lymphocytes, has also been described to work, in part, via $\mathrm{Ly} 49 \mathrm{H}$ activation via m157. This process takes on a similar "antigen" driven expansion phase which truly mimics that of the "classical" lymphocytes like CD8 $+\alpha \beta \mathrm{T}$ cell receptor+ lymphocytes (Sun et al., 2009).

The large number of Ly49 receptors lacking known ligands highlights another need in this field. There may be unconventional ligands for some of these receptors as well. For example, urokinase plasminogen activator has been identified as a ligand for Ly49E and it may play a role in wound healing or tissue growth (Van Den Broeck et al., 2008). It may be that some of the missing ligands may reveal novel functions for the Ly 49 genes beyond the simple killing of infected cells, inasmuch as a role for NK cells in placental development has been uncovered via HLA-G and KIR2DL4/CD158d interactions in human pregnancy (Bryceson and Long, 2008).

\section{CELLULAR EXPRESSION OF Ly49 GENES}

Along with the lack of known ligands for many Ly49 genes, there is very limited characterization of cells expressing Ly49 (Table 3). Only 11 of the Ly49 receptors have monoclonal antibodies that recognize them. Further complicating the issue, many of the antibodies are cross-reactive for more than one Ly49 gene.

Most Ly49 genes are found on NK cells, invariant NKT (iNKT) lymphocytes, and $\gamma \delta \mathrm{T}$ lymphocytes. Two of the 11 known genes were expressed on cells other than NK cells, notably Ly49Q which is found on myeloid cells and plasmacytoid dendritic cell (pDCs) subsets (Kamogawa-Schifter et al., 2005), and plays a role in maturation of these pDCs (Toma-Hirano et al., 2009) and activation of osteoclasts (Hayashi et al., 2010). Ly49B also is found on CD11b+ myeloid cells including macrophages, granulocytes, and mast cells, and there has been one report of Ly49B on activated NK and an iNK T cell line. Expression on Ly49B and Ly49Q are on nonoverlapping myeloid subsets, and can induce in NK cells (Gays et al., 2006). Subsets of CD8+ Tregs (as defined by CD44+, CD122+, and Qa-1 mediated suppression) express Ly49A, Ly49C/I (weakly), Ly49G2, but had substantial expression of Ly49F (Kim et al., 2011).

\section{ROLE OF Ly49 IN INFECTION}

Some Ly49 genes are critical for defense against viral pathogens, particularly MCMV (Makrigiannis and Anderson, 2000). This fits into the paradigm of NK killing of cells that lack MHC Class I expression due to herpes virus interference by several viral proteins (Orr et al., 2005; Temme et al., 2010). Few studies have looked at the role of Ly49 genes in other infections and in other animal models. Depletion of cells expressing rat Ly49s3/s4/i3/i4 proteins in rats led to increased bacterial load after infection by Listeria monocytogenes. Furthermore, infection caused an increase in cells expressing several different Ly49 molecules (Shegarfi et al., 2009). Ly49G2 expression dominates early in this process in mice as well (Barao et al., 2011). A separate study looking at Ly49 genes after Plasmodium yoelii infection found a decrease of Ly49A, C/I, D, and G2 expressing cells in the spleen but an increase in the liver (Roland et al., 2006). 
Our interest in the Ly49 genes came after studying host gene expression following infection by Francisella tularensis (Kingry et al., 2011). A hallmark of Francisella infection is the lack of a robust innate immune response thus allowing the bacterium to outpace host defenses and cause rapid disseminated infection (Hajjar et al., 2006; Bosio, 2011). The mouse model was used to track changes in host responses during infection with the live vaccine strain (LVS) as well as the highly pathogenic lab strain Schu4 as measured by full genome expression microarrays. We observed an overall decrease in expression of the Ly49G2 gene in the lungs of Schu4 infected mice, but increased expression of Ly49G2 at $120 \mathrm{~h}$ post infection in the lungs of LVS infected mice (Kingry et al., 2011). This may signify the ability of the highly virulent strain to evade host NK cells more efficiently than the LVS. Both the LVS and Schu4 strain caused widespread decreases in many other Ly49 genes in the spleen, particularly Ly49A, Ly49I, Ly 49H, and Ly49D. Ly49D expression in the spleen eventually increased following infection but only after extensive dissemination of both strains of the bacteria. Ly49A, D, and $\mathrm{H}$ are all activating receptors, while Ly49G and I are inhibitory receptors. These results are similar to what was observed with Listeria and Plasmodium species (Roland et al., 2006; Shegarfi et al., 2009). It is unclear why both activating and inhibitory receptors might be altered after infection but it may represent a route of host immune evasion by Francisella or changes in the activation potentials of NK and other Ly49 expressing cells

\section{REFERENCES}

Arase, H., Mocarski, E. S., Campbell, A. E., Hill, A. B., and Lanier, L. L. (2002). Direct recognition of cytomegalovirus by activating and inhibitory NK cell receptors. Science 296, 1323-1326.

Aust, J. G., Gays, F., Hussain, F., Butcher, G. W., Kist, R., Peters, H., et al. (2011). Mice lacking Ly49E show normal NK cell development and provide evidence for probabilistic expression of Ly49E in NK cells and T cells. J. Immunol. 186, 2013-2023.

Back, J., Angelov, G. S., Mariuzza, R. A., and Held, W. (2011). The interaction with $\mathrm{H}-2 \mathrm{Dd}$ in cis is associated with a conformational change in the Ly49A NK cell receptor. Front. Immunol. 2:55. doi:10.3389/fimmu.2011.00055

Back, J., Malchiodi, E. L., Cho, S., Scarpellino, L., Schneider, P., Kerzic, M. C., et al. (2009). Distinct conformations of Ly49 natural killer cell receptors mediate MHC class I recognition in trans and cis. Immunity 31, 598-608.

Barao, I., Alvarez, M., Ames, E., Orr, M. T., Stefanski, H. E., Blazar, B. R., et al. (2011). Mouse Ly49G2+ NK cells dominate early responses during both immune reconstitution and activation independently of MHC. Blood 117, 7032-7041.
Belanger, S., Tai, L. H., Anderson, S. K., and Makrigiannis, A. P. (2008). Ly49 cluster sequence analysis in a mouse model of diabetes: an expanded repertoire of activating receptors in the NOD genome. Genes Immun. 9, 509-521.

Bosio, C. M. (2011). The subversion of the immune system by Francisella tularensis. Front. Microbiol. 2:9. doi:10.3389/fmicb.2011.00009

Brodin, P., Lakshmikanth, T., Karre, K., and Hoglund, P. (2012). Skewing of the NK cell repertoire by MHC class I via quantitatively controlled enrichment and contraction of specific Ly49 subsets. J. Immunol. 188, 2218-2226.

Bryceson, Y. T., and Long, E. O. (2008). Line of attack: NK cell specificity and integration of signals. Curr. Opin. Immunol. 20, 344-352.

Chan, P. Y., and Takei, F. (1989). Molecular cloning and characterization of a novel murine $\mathrm{T}$ cell surface antigen, YE1/48. J. Immunol. 142, 1727-1736.

Cheng, T. P., French, A. R., Plougastel, B. F., Pingel, J. T., Orihuela, M. M., Buller, M. L., et al. (2008). Ly49h is necessary for genetic resistance to murine cytomegalovirus. Immunogenetics $60,565-573$.

Corbett, A. J., Coudert, J. D., Forbes, C. A., and Scalzo, A. A. (2011). Functional consequences of natural sequence variation of murine

responding to the infection. Together with the studies on MCMV infections, we suspect that these receptors are part of the host response to many different types of intracellular pathogens.

\section{SUMMARY}

Starting with the complex genetics of the Ly49 genes, there remain considerable gaps in our understanding of the precise and perhaps interactive roles of the receptors in the immune response. Even at a basic level, ligands and cellular expression patterns remain only partially deciphered. While the genes were originally linked to NK killing of tumors and recognition of viral infection, recent studies have shown roles for Ly49 on other cell types and with other functions in myeloid cells and the innate immune response. The likely requirements for these genes in combating intracellular viral, bacterial, and parasitic pathogens remain relatively unexplored as well. These intriguing results hint that there may be more functions of these receptors still to be discovered, especially as more is learned about the expression profiles and ligands of the Ly49 genes.

\section{ACKNOWLEDGMENTS}

We wish to thank Jamie S. Schenkel and Dr. Andrew P. Makrigiannis for critical reading of this manuscript. This work was supported in part by Rocky Mountain Regional Center of Excellence U54 AI065357.

cytomegalovirus m157 for Ly49 receptor specificity and NK cell activation. J. Immunol. 186, 1713-1722.

Corral, L., Takizawa, H., Hanke, T. Jamieson, A. M., and Raulet, D. H. (1999). A new monoclonal antibody reactive with several Ly49 NK cell receptors mediates redirected lysis of target cells. Hybridoma 18, 359-366.

Dam, J., Guan, R., Natarajan, K., Dimasi, N., Chlewicki, L. K., Kranz, D. M., et al. (2003). Variable MHC class I engagement by Ly49 natural killer cell receptors demonstrated by the crystal structure of Ly49C bound to H-2K(b). Nat. Immunol. 4, 1213-1222.

Dimasi, N., and Biassoni, R. (2005). Structural and functional aspects of the Ly49 natural killer cell receptors. Immunol. Cell Biol. 83, 1-8.

Dissen, E., Fossum, S., Hoelsbrekken, S. E., and Saether, P. C. (2008). NK cell receptors in rodents and cattle. Semin. Immunol. 20, 369-375.

Gays, F., Aust, J. G., Reid, D. M. Falconer, J., Toyama-Sorimachi, N., Taylor, P. R., et al. (2006). Ly49B is expressed on multiple subpopulations of myeloid cells. J. Immunol. 177, 5840-5851.

Hajjar, A. M., Harvey, M. D., Shaffer, S. A., Goodlett, D. R., Sjostedt, A., Edebro, H., et al. (2006). Lack of in vitro and in vivo recognition of Francisella tularensis subspecies lipopolysaccharide by Toll-like receptors. Infect. Immun. 74, 6730-6738.

Hara, T., Nishimura, H., Hasegawa, Y., and Yoshikai, Y. (2001). Thymusdependent modulation of Ly49 inhibitory receptor expression on NK1.1+gamma/delta T cells. Immunology 102, 24-30.

Hayashi, M., Nakashima, T., Kodama, T., Makrigiannis, A. P., ToyamaSorimachi, N., and Takayanagi, H. (2010). Ly49Q, an ITIM-bearing NK receptor, positively regulates osteoclast differentiation. Biochem. Biophys. Res. Commun. 393, 432-438.

Held, W., and Mariuzza, R. A. (2008). Cis interactions of immunoreceptors with $\mathrm{MHC}$ and non-MHC ligands. Nat. Rev. Immunol. 8, 269-278.

Held, W., Roland, J., and Raulet, D. H. (1995). Allelic exclusion of Ly49-family genes encoding class I MHC-specific receptors on NK cells. Nature 376, 355-358.

Johansson, S., Salmon-Divon, M., Johansson, M. H., Pickman, Y., Brodin, P., Karre, K., et al. (2009). Probing natural killer cell education by Ly49 receptor expression analysis and computational modelling in single $\mathrm{MHC}$ class I mice. PLoS ONE 4:e6046. doi:10.1371/journal.pone.0006046 
Jonsson, A. H., Yang, L., Kim, S., Taffner, S. M., and Yokoyama, W. M. (2010). Effects of MHC class I alleles on licensing of Ly49A+ NK cells. J. Immunol. 184, 3424-3432.

Kamogawa-Schifter, Y., Ohkawa, J., Namiki, S., Arai, N., Arai, K., and Liu, Y. (2005). Ly49Q defines 2 pDC subsets in mice. Blood 105, 2787-2792.

Kielczewska, A., Kim, H. S., Lanier, L. L., Dimasi, N., and Vidal, S. M. (2007). Critical residues at the Ly49 natural killer receptor's homodimer interface determine functional recognition of $\mathrm{m} 157$, a mouse cytomegalovirus MHC class I-like protein. J. Immunol. 178, 369-377.

Kielczewska, A., Pyzik, M., Sun, T., Krmpotic, A., Lodoen, M. B., Munks, M. W., et al. (2009). Ly49P recognition of cytomegalovirus-infected cells expressing $\mathrm{H} 2-\mathrm{Dk}$ and $\mathrm{CMV}$ encoded $\mathrm{m} 04$ correlates with the NK cell antiviral response. J. Exp. Med. 206, 515-523.

Kim, H. J., Wang, X., Radfar, S., Sproule, T. J., Roopenian, D. C., and Cantor, H. (2011). CD8+ T regulatory cells express the Ly49 Class I MHC receptor and are defective in autoimmune prone B6-Yaa mice. Proc. Natl. Acad. Sci. U.S.A. 108, 2010-2015.

Kim, S., Poursine-Laurent, J., Truscott, S. M., Lybarger, L., Song, Y. J., Yang, L., et al. (2005). Licensing of natural killer cells by host major histocompatibility complex class I molecules. Nature 436, 709-713.

Kingry, L. C., Troyer, R. M., Marlenee, N. L., Bielefeldt-Ohmann, H., Bowen, R. A., Schenkel, A. R., et al. (2011). Genetic identification of unique immunological responses in mice infected with virulent and attenuated Francisella tularensis. Microbes Infect. 13, 261-275.

Lavender, K. J., and Kane, K. P. (2006). Cross-species dependence of Ly49 recognition on the supertype defining B-pocket of a class I MHC molecule. J. Immunol. 177, 8578-8586.

Lee, S. H., Girard, S., Macina, D., Busa, M., Zafer, A., Belouchi, A., et al. (2001). Susceptibility to mouse cytomegalovirus is associated with deletion of an activating natural killer cell receptor of the C-type lectin superfamily. Nat. Genet. 28, 42-45.

Loch, S., and Tampe, R. (2005). Viral evasion of the MHC class I antigenprocessing machinery. Pflugers Arch. 451, 409-417.

Lowin-Kropf, B., Kunz, B., Beermann, F., and Held, W. (2000). Impaired natural killing of $\mathrm{MHC}$ class I-deficient targets by NK cells expressing a catalytically inactive form of SHP-1. J. Immunol. 165, 1314-1321.

Makrigiannis, A. P., and Anderson, S. K. (2000). Ly49 gene expression in different inbred mouse strains. Immunol. Res. 21, 39-47.

Makrigiannis, A. P., Gosselin, P., Mason, L. H., Taylor, L. S., McVicar, D. W., Ortaldo, J. R., et al. (1999). Cloning and characterization of a novel activating Ly49 closely related to Ly49A. J. Immunol. 163, 4931-4938.

Makrigiannis, A. P., Pau, A. T., Saleh, A., Winkler-Pickett, R., Ortaldo, J. R., and Anderson, S. K. (2001). Class I MHC-binding characteristics of the 129/J Ly49 repertoire. J. Immunol. 166, 5034-5043.

Makrigiannis, A. P., Pau, A. T., Schwartzberg, P. L., McVicar, D. W., Beck, T. W., and Anderson, S. K. (2002). A BAC contig map of the Ly49 gene cluster in 129 mice reveals extensive differences in gene content relative to $\mathrm{C} 57 \mathrm{BL} / 6$ mice. Genomics 79, 437-444.

Martin, A. M., Freitas, E. M., Witt, C. S., and Christiansen, F. T. (2000). The genomic organization and evolution of the natural killer immunoglobulin-like receptor (KIR) gene cluster. Immunogenetics 51, 268-280.

Mehta, I. K., Smith, H. R., Wang, J., Margulies, D. H., and Yokoyama, W. M. (2001). A "chimeric" C57l-derived Ly49 inhibitory receptor resembling the Ly49D activation receptor. Cell. Immunol. 209, 29-41.

Middleton, D., and Gonzelez, F. (2010). The extensive polymorphism of KIR genes. Immunology 129, 8-19.

Nylenna, O., Naper, C., Vaage, J. T., Woon, P. Y., Gauguier, D., Dissen, E., et al. (2005). The genes and gene organization of the Ly49 region of the rat natural killer cell gene complex. Eur. J. Immunol. 35, 261-272.

Orr, M. T., Edelmann, K. H., Vieira, J., Corey, L., Raulet, D. H., and Wilson, C. B. (2005). Inhibition of MHC class I is a virulence factor in herpes simplex virus infection of mice. PLoS Pathog. 1:e7. doi:10.1371/journal.ppat.0010007

Orr, M. T., and Lanier, L. L. (2011). Inhibitory Ly49 receptors on mouse natural killer cells. Curr. Top. Microbiol. Immunol. 350, 67-87.

Ortaldo, J. R., Winkler-Pickett, R., Mason, A. T., and Mason, L. H. (1998). The Ly-49 family: regulation of cytotoxicity and cytokine production in murine CD3+ cells. J. Immunol. 160, 1158-1165.

Roland, J., Soulard, V., Sellier, C., Drapier, A. M., Di Santo, J. P.,
Cazenave, P. A., et al. (2006). NK cell responses to Plasmodium infection and control of intrahepatic parasite development. J. Immunol. 177, 1229-1239.

Scarpellino, L., Oeschger, F., Guillaume, P., Coudert, J. D., Levy, F., Leclercq, G., et al. (2007). Interactions of Ly49 family receptors with $\mathrm{MHC}$ class I ligands in trans and cis. J. Immunol. 178, 1277-1284.

Shegarfi, H., Sydnes, K., Lovik, M., Inngjerdingen, M., Rolstad, B., and Naper, C. (2009). The role of natural killer cells in resistance to the intracellular bacterium Listeria monocytogenes in rats. Scand. J. Immunol. 70, 238-244.

Smith, H. R., Karlhofer, F. M., and Yokoyama, W. M. (1994). Ly-49 multigene family expressed by IL-2activated NK cells. J. Immunol. 153 1068-1079.

Sun, J. C., Beilke, J. N., and Lanier, L. L. (2009). Adaptive immune features of natural killer cells. Nature 457 557-561.

Tassi, I., Le Friec, G., Gilfillan, S., Takai, T., Yokoyama, W. M., and Colonna, M. (2009). DAP10 associates with Ly49 receptors but contributes minimally to their expression and function in vivo. Eur. J. Immunol. 39, 1129-1135.

Tay, C. H., Yu, L. Y., Kumar, V., Mason, L., Ortaldo, J. R., and Welsh, R. M. (1999). The role of LY49 NK cell subsets in the regulation of murine cytomegalovirus infections. J. Immunol. 162, 718-726.

Temme, S., Eis-Hubinger, A. M., McLellan, A. D., and Koch, N. (2010). The herpes simplex virus-1 encoded glycoprotein B diverts HLA-DR into the exosome pathway. J. Immunol. 184, 236-243.

To, K., Agrotis, A., Besra, G., Bobik, A., and Toh, B. H. (2009). NKT cell subsets mediate differential proatherogenic effects in ApoE-/- mice. Arterioscler. Thromb. Vasc. Biol. 29, 671-677.

Toma-Hirano, M., Namiki, S., Shibata, Y., Ishida, K., Arase, H., Miyatake, S., et al. (2009). Ly49Q ligand expressed by activated $\mathrm{B}$ cells induces plasmacytoid DC maturation. Eur. J. Immunol. 39, 1344-1352.

Toyama-Sorimachi, N., Tsujimura, Y. Maruya, M., Onoda, A., Kubota, T., Koyasu, S., et al. (2004). Ly49Q, a member of the Ly49 family that is selectively expressed on myeloid lineage cells and involved in regulation of cytoskeletal architecture. Proc. Natl. Acad. Sci. U.S.A. 101, 1016-1021.

Van Beneden, K., De Creus, A., Stevenaert, F., Debacker, V., Plum, J., and Leclercq, G. (2002). Expression of inhibitory receptors Ly49E and CD94/NKG2 on fetal thymic and adult epidermal TCR V gamma 3 lymphocytes. J. Immunol. 168, 3295-3302.

Van Beneden, K., Stevenaert, F., De Creus, A., Debacker, V., De Boever, J., Plum, J., et al. (2001). Expression of Ly49E and CD94/NKG2 on fetal and adult NK cells. J. Immunol. 166, 4302-4311.

Van Den Broeck, T., Stevenaert, F., Taveirne, S., Debacker, V., Vangestel, C., Vandekerckhove, B., et al (2008). Ly49E-dependent inhibition of natural killer cells by urokinase plasminogen activator. Blood 112, 5046-5051.

Yokoyama, W. M., Jacobs, L. B., Kanagawa, O., Shevach, E. M., and Cohen D. I. (1989). A murine T lymphocyte antigen belongs to a supergene family of type II integral membrane proteins. J. Immunol. 143, 1379-1386.

Yokoyama, W. M., Kehn, P. J., Cohen, D. I., and Shevach, E. M. (1990). Chromosomal location of the Ly49 (A1, YE1/48) multigene family. Genetic association with the NK 1.1 antigen. J. Immunol. 145, 2353-2358.

Yokoyama, W. M., and Seaman, W. E. (1993). The Ly-49 and NKR-P1 gene families encoding lectin-like receptors on natural killer cells: the NK gene complex. Annu. Rev. Immunol. 11, 613-635.

Conflict of Interest Statement: The authors declare that the research was conducted in the absence of any commercial or financial relationships that could be construed as a potential conflict of interest.

Received: 20 November 2012; accepted: 04 April 2013; published online: 16 April 2013.

Citation: Schenkel AR, Kingry LC and Slayden RA (2013) The Ly49 gene family. A brief guide to the nomenclature, genetics, and role in intracellular infection. Front. Immunol. 4:90. doi: 10.3389/fimmu.2013.00090

This article was submitted to Frontiers in Inflammation, a specialty of Frontiers in Immunology.

Copyright (C) 2013 Schenkel, Kingry and Slayden. This is an open-access article distributed under the terms of the Creative Commons Attribution License, which permits use, distribution and reproduction in other forums, provided the original authors and source are credited and subject to any copyright notices concerning any third-party graphics etc. 